\title{
ENGLISH STUDIES: A NOTE ON THE BIRTH AND USES OF THE TERM
}

\author{
Susana ONEGa \\ University of Zaragoza
}

\begin{abstract}
The need to adapt the current Spanish degree in English Philology to meet the requirements of the European Union has recently materialised in a growing conviction among scholars that the change of contents and format of the degree itself should be accompanied by a change of title, from "English Philology" to "English Studies". This move justifies the present attempt to briefly recall some of the main lines of discussion involved in the birth and uses of the term in Britain and abroad.
\end{abstract}

In the last forty years or so, the number of academic books and essays devoted to the analysis of the birth of English Studies has been not only too numerous to be mentioned but also widely divergent in their accounts of the phenomenon. Characteristically, early books written by British scholars, like D. J. Palmer's pathbreaking study, The Rise of English Studies: An Account of the Study of English Language and Literature from its Origins to the Making of the Oxford English School, published in 1965, present English Studies as a British phenomenon closely associated with the Universities of Oxford and Cambridge. According to Palmer (1965: vii-viii), the foundation of the Oxford School in 1893 was a decisive challenge to the long supremacy of classical studies, whose methods and principles they adopted "to secure the advent of English studies as a fully-developed branch of humane learning". The School of English at Cambridge was subsequently founded in 1917.

In an essay entitled "Englishness and English Studies", Balz Engler (2000a: 341) comments on the foundation of these schools and suggests that the difference in dates had important consequences, since "the type of English 
introduced at Oxford and Cambridge were strikingly different from each other, one characterised by its traditionally heavier emphasis on medieval literature, the other by its emphasis on literature as a both [sic] moral and life-giving force". At Oxford the teaching of English heavily relied on "the philological method for which nineteenth-century German scholarship was rightly famous, [while at] Cambridge nationalist rhetoric played an important role in the foundation of the School of English" (342). According to Engler, this difference in aim and approach to English Studies at Oxford and Cambridge evinces the increasing importance of the notion of nationality during and after the First World War, a difference that is documented in the influential Newbolt Report on The Teaching of English in England of 1921 and continued in F. R. Leavis's attempt to establish the canon of English literature in The Great Tradition (1948).

Engler's paper forms part of a collection of essays edited by Balz Engler and Renate Haas, entitled European English Studies: Contributions towards the History of a Discipline (2000). ${ }^{1}$ All essays in this book may be said to be aimed at challenging Palmer's narrow account, providing evidence for the importance of the European contribution to the rise and spread of English Studies in the world.

In the dustjacket of The Rise of English Studies (1965), Palmer's publisher summarises the subject of the book in the following terms:

The study of English literature began humbly as a kind of poor man's Classics, made popular by Victorian missionaries of culture, and its status as a university subject has always been controversial.

The publisher's remarks are significant in the assumptions he makes. He cuts down the book's subtitle, substituting "the study of literature" for "the study of language and literature", presents the rise of English Studies as a university phenomenon, and endorses the author's view that English Studies originated in England.

Even if we provisionally accept the equation of "English Studies" and "English Literature", the definition of "English" remains problematic. Thus, for example, in his contribution to the debate on the definition of English literature launched by Literature Matters (the newsletter of the British Council's Literature Department) in 1991, Antony Easthope (1991: 6) points to the existence of a well-established tradition of English national culture characterised by empiricism and objectivity, and represented by "the line from Hobbes to Locke and Hume". However, he immediately admits that, although,

1. See Onega (2002: 260-262). 
at the Renaissance, England did emerge as a particular nation state with a specific national culture, [....] in general, Englishness has been hidden by Empire. While the English felt they were called on to rule a third of the world, their sense of their own identity got lost in the claims that God was an Englishman.

Easthope's contention that the definition of Englishness has always been hidden by the Empire is ironised on and contested by Alan Riach in a subsequent issue of the same newsletter, where he contends that Easthope's assertions are vague and betray unexamined assumptions, one of which is contradicted by the fact that "Hume, of course, was not English at all, but [...] irredeemably Scottish". As Riach (1993: 6) further notes:

Following the Treaty of Union of 1707 , many Scottish writers set about inventing a British idiom, preserving the national characteristics in aspic, subjecting them to nostalgia, or pruning them remorselessly. This process can only be understood adequately in the wider context of the project of "empire", and not in any purely "literary" way. Such an understanding acknowledges the cultural distinctions between nations and how these can be submerged or oppressed.

Alan Riach's contention that English literature is in fact a Scottish invention echoes Robert Crawford's full-length studies Devolving English Literature (1992) and The Scottish Invention of English Literature (1998), while his insistence that the definition of English Studies is politically and ideologically charged and has to be analysed in the wider context of the project of "Empire", undermines the assumption that the rise of English Studies is exclusively a university phenomenon, implicitly suggesting that its origins are more varied and should be analysed within the frame of multicultural studies. From a multicultural perspective, the traditional outlook on the rise of English Studies of which D. J. Palmer's book is emblematic becomes totally inadequate, as can be seen from the wealth of new terms coined in the last decades as an alternative to "English literature". Charles Sarvan (1991: 6) points to the most commonly used when he reflects: "Commonwealth literature? Literatures in English? Post-colonial literature? Anglophone literature? New Literatures in English? These labels are unsatisfactory [...] and the search for a suitable signifier continues".

This type of terminological instability constantly crops up in academic discussions of English literature, sometimes even unconsciously. Thus, for example, although Anthony Easthope's already mentioned paper is entitled "What is English about English Literature?", the paper itself is not aimed at establishing the Englishness of the English literary canon, but rather "the tradition of English national culture" (Easthope 1991: 6), a move that transforms English Literature 
into an umbrella term allowing for the inclusion within it of popular literature as well as of cultural, film and media studies.

The problem of defining English literature is further complicated by the multicultural outlook on the concept of nationality. Thus, for example, when the poet Robert Crawford is asked to answer Kate Bostock's (1992: 4) question: "What constitutes Scottish writing apart from the fact that Scottish writers live in Scotland?", he willingly admits that "there isn't a monolithic entity called 'Scottish writing.' Scottish writing as far as I'm concerned historically for the last few centuries has been very clearly multicultural and multilinguistic".

In a spirited article published in The European English Messenger in 1996, Keith Battarbee (1996: 60) analyses Colin McCabe's attempt to "deconstruct" the term "English Studies" and to substitute it with "British Studies". He regards it as an example of "a constantly recurrent conceptual angst" caused by the conviction of "the problematic nature of 'British Studies' [and] reflected in the terminological instability between the older 'British Life \& Institutions' (BLI), 'civilisation' and 'Landeskunde,' or the contemporary battery of 'Cultural Studies,' 'British (Cultural) Studies,' etc". Battarbee's (61) explanation for this conceptual angst is that British Studies "suffers from having two distinct and not always compatible origins":

Outside the UK, British Studies has for the most part emerged in the context of modern-language departments, alongside other anglophone Area Studies programs. [...] Within the domestic British context, however, the parenthood of British Studies is quite different. It has been closely associated with "Cultural Studies" [...]. The intellectual roots here go back not to a Continental-style English Philology, but through Leavis to Arnold: a highly moral contemplation of the English navel by means of the English novel. [...] The domestic model thus leans towards critical introspection; the overseas one, towards empirical description.

Simplifying a great deal, we could say, therefore, that one basic difference between the rise of English Studies in Britain and abroad has been the ancillary nature of English language with regard to English literature and culture in English Departments in the UK. To this should be added the fluctuations of the political and social situation in each individual country, which, according to critics outside the UK, have been and continue to be decisive in the shaping of English Studies in the world. As Krystyna Kujawinska-Courtney (2000: 61) puts it in her contribution to European English Studies: Contributions towards the History of a Discipline: "Each educational system is a reflection of a certain political, social, economic and cultural situation, and its practices seem to reflect the endorsement of or conflict with the prevailing ideology of the time". 
In the introduction to the same volume, Balz Engler (2000b: 2-3) widens the dichotomy established by Keith Batterbee when he contends that the British outlook on English Studies is also the rule in other English-speaking countries, where

"English" refers exclusively to the study of literature(s), not only English, but also American, Scottish, Welsh, Irish, Australian, New Zealand, Black British, and (as the euphemism goes) emerging ones. This may increasingly be complemented by aspects of cultural studies. Elsewhere, literature and linguistics are both integral parts of "English" and, as this tends to be the case where English is a foreign language, applied linguistics and language learning will, to different degrees, belong to it as well.

As Engler (6) further notes, "in most European countries English as a university discipline was introduced because there was a need for academic professionals, especially school teachers at the upper level, [...] English was therefore heavily dependent on the school system it served, which is organised differently in different countries".

A simple perusal of the papers about the rise of English Studies in specific European countries included in European English Studies would show how decisive the historical, political and linguistic factors have been in the rise of English Studies there. Thus, for example, as Martin A. Kayman (2000: 15) points out, the centuries-long political and commercial alliances between England and Portugal would explain the keen interest the Portuguese have always had for English language and culture. Likewise, the beginning of the tradition of studying English alongside with German at university level is closely linked to the political alliance between Portugal and Britain made on the eve of the First World War. By contrast, as Tomás Monterrey (2000: 34, 37) explains, the influence of French culture on Spanish intellectual life delayed the rise of English Studies in Spain until the opening up of Franco's regime in the 1950s and 1960s and is related to the establishment of the British Council in Madrid and the signing of the Economic and Military Agreement with the United States in 1952. To these external influences might be added an internal one, the creation of the first "Official School of Languages" in Madrid (first called "Central School of Languages") in the nineteen sixties with the aim of training Spaniards in modern European languages for commercial and practical purposes, including the government plans to transform Spain into a paradise for foreign tourists. Still, as Balz Engler (2000b: 8) notes, it was the United States that played an increasingly relevant role in the rise of English Studies in Europe "in the wake of the two World Wars, a symbolical moment being Wilson's insistence on the Treaty of Versailles being in English. 
Especially after World War II, and in the Cold War this influence became persuasive, and also led to the establishment of new English departments (as, for example, in Spain)". Or, we may add, in France, where, according to Imelda Bonet-Elliott (2000: 75), "American Studies became more widespread as America emerged as a world power".

In the case of eastern countries behind the Iron Curtain, the ideological and political components in the rise of English Studies was even more prominent. The establishment of university degrees in English were heavily financed by institutions like the UNESCO or the British Council, originally called the "British Committee for Relations with Other Countries", formed in November 1934 with the support of the Foreign Office (Kayman 2000: 17). Needless to say, the survival of these degrees was wholly determined by the twists and turns of international affairs and of political upheavals beyond the control of the academia, whose members might at times run the risk of ostracism and imprisonment (KujawinskaCourtney 2000: 161-181).

As the collection of essays shows, the historical, political and linguistic factors contributing to the rise of English Studies in each of the fifteen European countries under discussion were very varied and of unequal importance. A similar variety of external factors may be said to have conditioned the rise of English Studies in English-speaking countries belonging to the Commonwealth, like India, New Zealand or Australia. However, in these countries, unlike the European countries mentioned above, the basic determining factor in the rise of English Studies was, as Gauri Viswanathan (in Engler 2000a: 339-340) points out with reference to India, "the imperial mission of educating and civilising colonial subjects in the literature and thought of England. [...] the teaching of English literature was introduced to correct the negative view of the English created by the behaviour of the colonial masters".

A striking phenomenon that invariably accompanies the imperialist mission is the attempt to achieve linguistic globalization, what John E. Joseph (1999: 51-71), following C. K. Ogden, calls "Debabelization", that is, the materialization of the western dream of creating an artificial common language with which to undo the effects of God's punishment of humankind at Babel.

As John E. Joseph (1999: 54-56) notes, from the Renaissance onwards this idea has been a constant in western linguistic thought, reaching a climax in the nineteenth and early twentieth centuries, when the notion of creating a Universal Language was seriously entertained by linguists such as Johann Martin Schleyer (1831-1912), Otto Jespersen (1860-1943) and Edward Sapir (1884-1939). Another was C. K. Ogden (1888-1957), who was fascinated by the possibility of "the continuous approximation of East and West, as a result of the analytic character 
of Chinese and English" (Joseph 1999: 61). In a series of articles published between 1927 and 1930, Ogden contended that the best way to achieve "linguistic internationalization" or "Debabelization" was not by the creation of an artificial language, but by "a 'simplified universal English' to be devised through vocabulary reduction" (Joseph 1999: 57). With the help of Ivor Armstrong Richards, he founded the Orthological Institute in 1927 and worked on the creation of "Basic English". In 1932, he succeeded in obtaining support from the Payne Fund of New York, supplemented the following year by the Rockefeller Foundation, to sponsor research programmes for the "Debabelization" of Japan and China. He established a branch of the Orthological Institute in Beijing in order to develop the teaching of Basic English in China, which he did with the support of the Chinese government, using new technologies like the radio. The parallel programme in Japan, which would have been complete in 1942, was interrupted in 1938 by the Japanese invasion of China and, definitively cancelled in 1941, by the full-scale entry of Japan into world war (Joseph 1999: 61).

After World War II "the Basic English Foundation had to contend with lack of support and even outright hostility [... as] the British Council moved steadily toward a unified policy that 'natural' English was altogether preferable to Basic for teaching purposes" (63-64). By then, however, English was well on its way to becoming the second language of the East, in addition to its development in the United States, Canada, and Australasia.

As Joseph (64) further notes, of the 30 languages now at the head of the list, English has first place among the eight which are used by more than 50,000,000 people, the others being Chinese, Russian, French, Japanese, German, Spanish and Bengali. According to Joseph (65), a strong motivating force for the Chinese government to support the efforts to spread Basic English in China was their own lack of a standard spoken Chinese, so that "Basic English might serve as a shared language for Chinese from north to south as well as facilitating their contact and exchange with the rest of the world". This perspective, which would also be applicable to countries like India, completes and nuances the imperialist explanation for the rise of English Studies in the Far East, and by extension in other non-English speaking countries which have felt the need to incorporate English Studies into their curriculum, for it should not be forgotten that, as C. K. Ogden (in Joseph 2000: 62) himself notes,

Neither those who learn English nor those who teach it as a foreign language have in general any feeling that they are submitting to or furthering a process of intellectual subjugation. On the contrary, they are more likely to feel that they are helping themselves or others to resist such influences. 
Surely, for all the victimist discourse of narrow nationalism, many non-native speakers of English would be ready to endorse this view. If the traditional account of the rise of English Studies in the world has to be corrected, then, it is here, perhaps, that we should apply the correction, for, in addition to the contribution to the rise of English Studies made by English universities, on the one hand, and the effect of the British and US imperialist policy of cultural expansion and linguistic globalization, on the other, the total picture would also necessarily include the willingly active role played in the past by non-English speaking countries in the rise and spread of English Studies in the world. Needless to say, the convergence of university degrees in all Departments of English of the European Union, with its demand that we participate in the reconfiguration and updating of English Studies, will offer us an unparalleled opportunity to round off this aim.

\section{REFERENCES}

Battarbee, Keith. 1996. "British Studies Angst." The European English Messenger 5. 1: 60-62.

Bonet-Elliott, Imelda. 2000. "English Studies in France." European English Studies: Contributions towards the History of a Discipline. Eds. Balz Engler and Renate Haas. Great Britain: The English Association for ESSE. 69-88.

Bostock, Kate. 1992. "Literary Periodicals in Focus: Verse. Robert Crawford Interviewed by Kate Bostock." Literature Matters 11 (September): 4-5.

Crawford, Robert. 1992. Devolving English Literature. Oxford: Oxford University Press.

Crawford, Robert, ed. 1998. The Scottish Invention of English Literature. Cambridge: Cambridge University Press.

Easthope, Antony. 1991. "What is English about English Literature?" Literature Matters 9 (December): 6.

Engler, Balz. 2000a. "Englishness and English Studies." European English Studies: Contributions towards the History of a Discipline. Eds. Balz Engler and Renate Haas. Great Britain: The English Association for ESSE. 335-348.

Engler, Balz. 2000b. "Introduction." European English Studies: Contributions towards the History of a Discipline. Eds. Balz Engler and Renate Haas. Great Britain: The English Association for ESSE. 1-12.

Engler, Balz and Renate Hass, eds. 2000. European English Studies: Contributions towards the History of a Discipline. Great Britain: The English Association for ESSE. 
Joseph, John E. 1999. "Basic English and the Debabelization of China." Intercultural Encounters - Studies in English Literatures. Essays Presented to Rüdiger Ahrens on the Occasion of His Sixtieth Birthday. Eds. Heinz Antor and Kevin L. Cope. Heidelberg: C. Winter. 51-71.

Kayman, Martin A. 2000. "A Very Old Alliance? An Introduction to English in Portugal." European English Studies: Contributions towards the History of a Discipline. Eds. Balz Engler and Renate Haas. Great Britain: The English Association for ESSE. 13-32.

Kujawinska-Courtney, Krystina. 2000. "Masters and Teachers: English Studies in Poland." European English Studies: Contributions towards the History of a Discipline. Eds. Balz Engler and Renate Haas. Great Britain: The English Association for ESSE. 161-181.

Monterrey, Tomás. 2000. "Notes for a History of English Studies in Spain." European English Studies: Contributions towards the History of a Discipline. Eds. Balz Engler and Renate Haas. Great Britain: The English Association for ESSE. 33-52.

Onega, Susana. 2002. "Review of European English Studies: Contributions Towards the History of a Discipline." Revista Canaria de Estudios Ingleses 43: 260-262.

Palmer, D. J. 1965. The Rise of English Studies: An Account of the Study of English Language and Literature from its Origins to the Making of the Oxford English School. Oxford, New York, Toronto: Oxford University Press.

Sarvan, Charles. 1991. "Redefining English Literature." Literature Matters 9 (December): 6.

Riach, Alan. 1993. "At Home and Abroad." Literature Matters 12 (Christmas 1992 New Year): 6. 
